\title{
Joint leverage and maturity choices in real estate firms: The role of the REIT status
}

\author{
Jamie T. Alcock • Eva Steiner - Kelvin J. K. \\ Tan
}

Received: date / Accepted: date

\begin{abstract}
We explore the interdependence of leverage and debt maturity choices in Real Estate Investment Trusts (REITs) and unregulated listed real estate investment companies in the U.S. for the period 1973-2011. We find that the leverage and maturity choices of all listed real estate firms are interdependent, but in contrast to industrial firms, they are not made simultaneously. Across the different types of real estate firms considered, we find substantial differences in the nature of the relationship between leverage and maturity. Leverage determines maturity in non-REITs, whereas maturity is a determinant of leverage in REITs. We suggest that the observed differences reflect the effects of the REIT regulation, rather than solely being a function of real estate as the underlying asset class. We also present novel evidence that the relationship between leverage and maturity in both firm types can be used to moderate the effects of other exogenous financing policies.
\end{abstract}

Keywords Leverage · Debt Maturity · Capital Structure · JEL: G32, G01

\section{Introduction}

Capital structure arguably plays a unique role in the real estate investment industry due to the suitability of the underlying assets as debt security and the special tax treatment afforded to REITs. A substantial body of literature explores the determinants of leverage and debt maturity in listed real estate firms in isolation. ${ }^{1}$ However, with the exception of

We thank Shaun Bond, Colin Lizieri, Steffen Sebastian, Felix Schindler, Carolina Fugazza, Richard Barkham, Robin Goodchild, Shu Tian and two anonymous referees for their helpful comments and suggestions, along with the participants of the 17th European Real Estate Society Conference 2010, the 2nd RECAPNET Conference 2010, the 23rd Australasian Finance and Banking Conference 2010 and the First Annual International Real Estate Symposium at Renmin University, Beijing, as well as seminar participants at the University of Cambridge.

Jamie Alcock

Department of Land Economy, The University of Cambridge, 19 Silver Street, Cambridge, CB3 9EP, UK Tel.: +44-1223-337152

Fax: +44-1223-337130

E-mail: jta27@cam.ac.uk

Eva Steiner

Department of Land Economy, The University of Cambridge, 19 Silver Street, Cambridge, CB3 9EP, UK

Tel.: +44-1223-337147

Fax: +44-1223-337130

E-mail: es434@cam.ac.uk

Kelvin J. K. Tan

UQ Business School, The University of Queensland, Brisbane, St Lucia, 4072, Australia

Tel.: +61-7-3346-8051

Fax: +61-7-3346-8166

E-mail: j.tan@business.uq.edu.au

1 See, for example, Boudry, Kallberg, and Liu (2010); Brounen and Eichholtz (2001); Brown and Riddiough (2003); Ghosh, Nag, and Sirmans (1997, 1999, 2000); Highfield, Roskelley, and Zhao (2007). 
Giambona, Harding, and Sirmans (2008), little research focuses on the multidimensionality of capital structure choices in the real estate industry. When a firm decides to issue debt, the maturity of the debt contract has to be determined simultaneously. We explore the joint leverage and maturity choices of REITs and comparable non-regulated real estate firms, focussing especially on the effect of the REIT regulation on the interdependence between leverage and maturity choices.

Capital structure theory does not clearly predict the nature of the interaction between leverage and maturity choices in REITs and comparable unregulated real estate firms. We argue that, in the presence of corporate taxes, non-REITs prioritise the choice of an optimal target level of leverage following the trade-off theory. Optimal maturity is then a monotonic function of leverage, chosen to reduce cost of debt and refinancing risk, consistent with Alcock, Finn, and Tan (2011) who argue that firms determine the maturity of a debt issuance only once they have decided to issue debt. Conversely, we argue that REITs, that are generally exempt from corporate taxation, prioritise the maturity choice, following Leland and Toft (1996), and then determine the corresponding value-maximising level of leverage. We assess the empirical evidence for the hypothesised difference in the joint leverage and maturity decisions of REITs and comparable unregulated listed real estate firms.

Giambona et al (2008) also study the joint determination of leverage and maturity in REITs. They find that leverage and maturity are simultaneously determined and utilised as substitutes to mitigate underinvestment, consistent with Barclay, Marx, and Smith (2003). Giambona et al (2008) thus establish a fundamental difference between the capital structure choices of REITs and industrial firms. The latter group of firms appears to employ leverage and maturity as complements to reduce refinancing risk, in line with Johnson (2003).

However, the reason for this observed difference between industrial and real estate firms is unclear. REIT capital structure choices may be inconsistent with those of industrial firms due to the characteristics of real estate as the underlying asset class. In this case, we expect REITs and non-REITs to behave alike in the joint determination of leverage and maturity. Alternatively, the regulatory status of REITs, especially the tax exemption, may be the key driver, as taxes are crucial in traditional capital structure theory. If this were the case, then we expect see REITs and comparable non-REITs make capital structure decisions differently from each other.

In order to provide robust empirical evidence for the hypothesised relationships between leverage and maturity choices in REITs and non-REITs, we need to address two potential endogeneity issues. The joint determination of leverage and maturity introduces a simultaneity bias. We mitigate this problem by adopting an instrumental variable approach and estimate a 2SLS system of equations for leverage and maturity. In addition, a firm's choice of corporate structure (REIT vs/ non-REIT) may also be endogenously determined. We identify the effect of REIT status on the interdependence between leverage and maturity by employing a modified difference-in-differences (DD) estimator in connection with the 2SLS estimation.

We find that, in contrast to industrial firms, REITs and non-REITs do not appear to determine leverage and maturity simultaneously and thus do not seem to employ these two dimensions of capital structure as complements or substitutes. We suggest that leverage and maturity can only be chosen simultaneously when other incentives to prioritise one of the choices exactly offset each other. Within the real estate sector, the drivers of capital structure choices, and especially the interrelationship between leverage and maturity, reflect the effects of the REIT regulation and the exemption from corporate taxation. Leverage determines maturity in non-REITs, in line with Alcock et al (2011), whereas maturity is a determinant of leverage in REITs, consistent with Leland and Toft (1996). Overall, the REIT status appears to free up scope in the capital structure to pursue more offensive strategies, such as signalling firm quality to the market and optimising transaction costs, while non-REITs largely seem to focus on defensive objectives such as the mitigation of tax, agency costs and refinancing risk. We also present novel evidence that the relationship between leverage and maturity in both firm types can be used to moderate the effects of exogenous financing policies. 
We review related literature in Section 2. Section 3 provides details on data, identification strategy and methodology. Section 4 discusses the empirical results. Section 5 concludes.

\section{Literature review}

Leland and Toft (1996) examine the optimal capital structure of a firm that can choose leverage and maturity. They argue that optimal leverage is a function of firm risk, expected bankruptcy costs and maturity. Indirectly they argue that firms choose maturity first, then determine the corresponding value-maximising level of leverage. The optimal, value-maximising leverage ratio increases with maturity. Alcock et al (2011) argue that firms determine leverage first, and then choose the corresponding most cost-efficient term to maturity. The relative economies that can be achieved by issuing longer-maturity debt increase with the pre-issuance level of leverage. Barclay et al (2003) propose that leverage and maturity can act as substitutes to mitigate the underinvestment problem. Empirically, Johnson (2003) finds that leverage and maturity are complements to reduce refinancing risk. Existing theory does not offer explicit guidance on the expected relationships between leverage and maturity in real estate firms. Empirical research into this question is sparse. A notable exception is Giambona et al (2008) who study joint leverage and maturity choices in REITs. They find that leverage and maturity appear to be substitutes in the sense of Barclay et al (2003).

The interest in real estate and especially REIT capital structure choices is partly fuelled by the fact that the major traditional theories of corporate leverage are not easily applicable to real estate firms and especially to REITs. Trade-off theory posits a value-maximising debt ratio where the marginal bankruptcy costs and tax benefits of debt are equal. ${ }^{2}$ However, REITs are exempt from corporate tax if they distribute $90 \%$ of taxable income as dividends, which nullifies tax shields and some agency costs of debt. Howe and Shilling (1988) assert that in the absence of tax benefits, REITs cannot compete for debt and will favour equity. Shilling (1994) argues that REIT value is maximised for equity-only financing. Consistently, Ghosh et al (1997) find that REITs raise more capital through seasoned equity than debt. Boudry et al (2010) find that REITs are less likely to issue debt when bankruptcy costs are high and interpret this as support for the trade-off theory. Brown and Riddiough (2003) present evidence in support of the view that, consistent with the existence of an optimal leverage ratio implied in trade-off theory, REITs appear to target a certain leverage ratio. However, this strategy appears to be motivated by the maintenance of an investment-grade rating.

Pecking order theory ${ }^{3}$ claims that capital structure changes reflect a need for external funds given the higher informational sensitivity and thus adverse selection costs of equity. Boudry et al (2010) argue that REITs especially are a fairly transparent investment vehicle as they focus on cash yields and stable cash flows from the operation of real estate, questioning the existence of asymmetric information. On the other hand, Han (2006) argues that accurate real estate valuation requires sophisticated local knowledge, increasing information asymmetry. Pecking order also assumes discretion over earnings, debt and equity. However, REIT pay-out requirements restrict funding choices to debt and equity. Accordingly, Boudry et al (2010) find no evidence for pecking order in REIT financing choices. Nevertheless, several studies confirm the negative price and valuation effects of equity issues implied in pecking order (Brounen and Eichholtz, 2001; Ghosh et al, 1999, 2000; Howe and Shilling, 1988). Feng, Ghosh and Sirmans (2007) show that REITs balance the lack of incentive for debt and the adverse selection cost of equity.

Research into maturity choices in real estate is sparse. Howe and Shilling (1988) find REIT stock prices increase after short-term debt issues. This finding is consistent with the signalling hypothesis proposed in Flannery (1986) who develops an inverse relationship between debt maturity and firm quality. High quality is signalled through issuing short-term

\footnotetext{
2 Variations are explored in DeAngelo and Masulis (1980); Jensen (1986); Kraus and Litzenberger (1973) and Modigliani and Miller (1963).

3 See e.g. Donaldson (1961); Myers (1984); Myers and Majluf (1984); Shyam-Sunder and Myers (1999)
} 
debt to exploit favourable refinancing terms. Brown and Riddiough (2003) find a negative relationship between REIT debt maturity and credit ratings. This result resonates the liquidity risk theory (Diamond, 1991; Sharpe, 1991; Titman, 1992) that predicts an inverse relationship between credit rating and debt maturity as lower-rated firms attempt to avoid risky refinancing events. Highfield et al (2007) find little evidence for signalling and liquidity risk in REITs but confirm the influence of personal taxes and agency problems.

On balance, many of the existing capital structure theories are not fully applicable to the special circumstances of REITs. In fact, theory predicts that REITs should not use leverage at all. Yet, anecdotal evidence suggests that REITs typically carry significant levels of leverage. Most of the existing research on the capital structure of REITs therefore focuses on analysing leverage choices. When maturity choices are considered, then typically in isolation and rarely in conjunction with leverage decisions. We contribute to the literature by providing additional insight into the joint determination of leverage and maturity in REITs and comparable non-REITs.

\section{Data and methodology}

\subsection{Data and proxies}

We study all firms that form part of the real estate industry in the Standard Industry Classification (SIC) system. We form three major groups, i) REITs (SIC 6798), ii) real estate firms that perform services comparable to REITs (same line of business, SLOB, firms from SIC 651), and iii) other real estate firms that provide different services (non-SLOB firms, SIC 1531, 653, 654, 655). We begin our sample in 1973, the first year for which Compustat has complete debt maturity data, and end in 2011. We replicate our analysis for the sub-periods before (1973 to 2006) and during (2007 to 2008) the global financial crisis. Our final sample for the main study period (1973 to 2011) consists of 1,586 firm-year observations.

We measure leverage as the ratio of total debt (long-term debt plus current liabilities) to market value of assets (book value of assets less book value of common equity plus market value of common equity), consistent with Billett, King, and Mauer (2007); Datta, IskandarDatta, and Raman (2005); Stohs and Mauer (1996). We use the ratio of long-term debt (debt due after three years) to total debt as our proxy for maturity (Barclay et al, 2003). The measurement of debt maturity varies in the literature, but fortunately with little impact on empirical results (Scherr and Hulburt, 2001). We consider a comprehensive set of control variables commonly employed in the capital structure literature. Table 1 outlines our control variables and their proxies. The proxies follow the suggestions of the original authors where possible. All firm data is obtained from Compustat. Bond yields have been obtained from the Federal Reserve Bank of St. Louis's Economic Database. All variables except earnings volatility and abnormal earnings are measured at the fiscal year-end prior to the year in which leverage and maturity are measured (Billett et al, 2007; Datta et al, 2005; Johnson, 2003).

In contrast to Giambona et al (2008) we employ different measures for debt and asset maturity. We include a time series of earnings volatility (Bradley, Jarrell, and Kim, 1984), rather than a single average value. We also control for debt rating (Diamond, 1991; Sharpe, 1991; Titman, 1992) and include operating loss carry-forward and investment tax credit dummies (DeAngelo and Masulis, 1980) as proxies for the trade-off theory. Lastly, we lag all our independent variables (Billett et al, 2007; Datta et al, 2005; Johnson, 2003).

\subsection{Identification strategy}

We aim to isolate the effect of the REIT status on capital structure choices and especially on the relationship between leverage and maturity decisions. We analyse the joint leverage and maturity choices in a pair of simultaneous equations to account for endogeneity. We estimate the system using 2SLS, consistent with Barclay et al (2003); Giambona et al (2008); Johnson 
(2003). In order to identify the REIT effect, we cannot simply pool REITs and comparable non-REITs and test the significance of an interaction term between the indicator variable for REITs with maturity (leverage) in the leverage (maturity) equation, as REIT status may also be endogenously determined. However, to the best of our knowledge, the literature generally offers no guidance on suitable instruments for the REIT status choice. In order to mitigate this endogeneity bias, we adopt a modified difference-in-differences (DD) approach and incorporate this into the 2SLS system.

The DD technique is used to identify the treatment effects of changes in the firm's economic or institutional environment (Ashenfelter and Card, 1985; Bertrand and Mullainathan, 2003; Card and Krueger, 1994; Hong, Kubik, and Scheinkman, 2011; Roberts and Whited, 2011). The approach combines the comparison of the conditional expectation of the outcome variable in the treatment group before and after treatment with that of a control group before and after the date of the treatment. The DD estimator thus creates an intermediate counterfactual outcome that helps separate the treatment effect on the dependent variable from variation in this variable that would have happened even in the absence of treatment, for instance due to an exogenous time trend that affects the treatment and control groups equally.

We replace the time dimension typically considered in DD studies with a distinction between firms along their line of business. We assume that this distinction is exogenous, which seems reasonable since the business activity of a firm is chosen before the firm is founded and typically remains the same throughout the life of the firm. We choose this distinction on the basis of the assumption that REITs and comparable non-REIT firms (same line of business, SLOB, firms) are essentially identical, except for the REIT status and potentially a set of observable characteristics that we control for in our regression. We create dummy variables denoting the group to which a firm belongs, REIT $=1$ for REIT firms, $\mathrm{SLOB}=1$ for REIT firms (except mortgage REITs) and SLOB firms. Then, RE is the default group for other non-SLOB firms. This set-up produces four combinations of firm type indicators.

\begin{tabular}{l|c|c}
\hline Dummy variables & REIT & non-REIT \\
\hline SLOB & $1-1$ & $1-0$ \\
Other RE (non-SLOB) & $0-1$ & $0-0$ \\
\hline \hline
\end{tabular}

A typical equity REIT is in category 1-1 as it provides a REIT-type service and operates under the REIT regime. A SLOB firm provides a comparable service but operates outside the REIT regime, resulting in category 1-0, a mortgage REIT is in category $0-1$, and Other RE firms that provide a different service such as developers are in category 0-0. These categories produce the following combinations of coefficients in a regression of an outcome $y$ on firm types, with Other RE as the base category, that is $y=\beta_{0}+\beta_{1} R E I T^{*} S L O B+\beta_{2} R E I T+$ $\beta_{3} S L O B+$ residual.

\begin{tabular}{l|c|c|c}
\hline Coefficients & REIT & non-REIT & Difference \\
\hline SLOB & $\beta_{0}+\beta_{1}+\beta_{2}+\beta_{3}$ & $\beta_{0}+\beta_{3}$ & $\beta_{1}+\beta_{2}$ \\
\hline Other RE (non-SLOB) & $\beta_{0}+\beta_{2}$ & $\beta_{0}$ & $\beta_{2}$ \\
\hline Difference & $\beta_{1}+\beta_{3}$ & $\beta_{3}$ & $\beta_{1}$ \\
\hline \hline
\end{tabular}

The double-difference coefficient $\beta_{1}$ captures the net effect of REIT status after controlling for the line of business. Roberts and Whited (2011) discuss the DD method as a way of addressing common endogeneity issues in detail. Other observable controls that may differentiate firms and affect the outcome can be added to the equation. We then estimate the 2SLS system for leverage $(L E V)$ and maturity $(M A T)$ :

$$
\begin{aligned}
L E V_{i t} & =\beta_{0}+\beta_{1} R_{E I T^{*}} S L O B^{*} M A T_{i t} \\
& +\beta_{2} R E I T_{i t}+\beta_{3} S L O B_{i t}+\beta_{4} M A T_{i t}+\beta_{5}^{\prime} C T R L_{i t}+u_{i t} \\
M A T_{i t} & =\gamma_{0}+\gamma_{1} R E I T^{*} S L O B^{*} L E V_{i t} \\
& +\gamma_{2} R E I T_{i t}+\gamma_{3} S L O B_{i t}+\gamma_{4} L E V_{i t}+\gamma_{5}^{\prime} C T R L_{i t}+\eta_{i t}
\end{aligned}
$$


We interact the variable that produces the true effect of REIT status $\left(R E I T^{*} S L O B\right)$ with maturity and leverage, respectively. A significant coefficient $\beta_{1}\left(\gamma_{1}\right)$ in the leverage (maturity) equation is then evidence consistent with the hypothesis that the joint determination of leverage and maturity differs between REITs and non-REITs as a result of the REIT regulation. The matrix $C T R L$ contains the control variables outlined in Table 1.

We are careful not to include controls that may themselves by affected by the REIT status, such as dividend policy, potentially rendering them endogenous. We include year fixed effects in the maturity equation to control for latent macroeconomic factors. The $u_{i t}$ and $\eta_{i t}$ are normal residuals. Standard errors are clustered by firm.

In order to explore the relationship between leverage and maturity for SLOB firms, we repeat the 2SLS regressions above, but exclude REITs (categories 1-1 and 0-1). Given our assumption of exogeneity, the 'line of business effect' can be captured by pooling $S L O B$ and $R E$ firms and assessing the significance of the interaction between $S L O B$ and $L E V$ $(M A T)$ in the maturity (leverage) equation. The comparison of the results from the estimation including REITs and the estimation excluding REITs allows us to contrast the nature of the interrelationship between leverage and maturity in the two firm types. We expect $R E I T^{*} S L O B^{*} M A T$ to be positively related to REIT leverage, and $S L O B^{*} L E V$ to be positively related to maturity for SLOB firms. As before, standard errors are clustered by firm.

Lastly, we separate REIT from non-REIT firms to explore the influence of other factors commonly reported in the capital structure literature. This step allows us to explore the potential wider consequences on capital structure policies of the interrelationships between leverage and maturity in REITs and non-REITs in more detail. Our results are qualitatively similar when controlling for mortgage REITs as well as for SIC categories 1531, 653, 654, and 655 . We estimate the systems for leverage $(L E V)$ and maturity $(M A T)$ :

$$
\begin{aligned}
L E V_{i t} & =\beta_{0}+\beta_{1} M A T+\beta_{2}^{\prime} C T R L_{i t}+u_{i t} \\
M A T_{i t} & =\gamma_{0}+\gamma_{1} L E V+\gamma_{2}^{\prime} C T R L_{i t}+\eta_{i t}
\end{aligned}
$$

Again, we estimate our regressions using 2SLS with standard errors clustered by firm, rather than 3SLS. Empirical evidence for the interdependence of leverage and maturity appears to be sensitive to model specification (Barclay et al, 2003; Giambona et al, 2008). If both equations are misspecified because a variable that affects leverage and maturity has been omitted, this produces cross-equation correlation of residuals, suggesting that 3SLS may be more efficient. However, specification errors in one equation may be propagated through the 3SLS system. Limited-information estimators such as 2SLS confine a specification problem to the equation in which it occurs (Greene, 2002). Given the uncertainty surrounding the preferable specification, we choose to employ 2SLS.

\subsection{Descriptive statistics}

Panel A of Table 2 (Table 2) shows the distribution of debt maturity between 1973 to 2010 for REITs (non-REITs). REITs tend to borrow longer term than non-REITs, suggesting better access to long-term debt or fewer refinancing risks for REITs. The distribution of REIT debt maturity is highly left-skewed whereas the distribution for non-REITs appears almost uniform.

Panel B of Tables 2 (REITs) and 2 (non-REITs) presents descriptive statistics for all variables over the study period. According to simple $t$-tests, the mean firm value for REITs $(\$ 1,822 \mathrm{~m})$ is statistically larger than that for non-REITs $(\$ 701 \mathrm{~m})$. Average REIT debt maturity and leverage are significantly higher for REITs than for non-REITs $(61 \%$ and $45 \%$ relative to $49 \%$ and $41 \%$, respectively).

REITs have average asset maturity of 24 years, similar to that of non-REITs (20 years), but both are higher than for industrial firms at 12 years (Billett et al, 2007), consistent with the notion that the useful life of real estate assets is relatively long. REIT growth opportunities (1.26) are lower than for non-REITs (1.31). Lower growth opportunities in 
REITs, which are generally viewed as value-stocks, might suggest that some aspects of debtequity agency conflicts are of lesser concern. REIT earnings volatility (0.04) is significantly lower than for non-REITs (0.06). This is consistent with the view that REITs focus on stable income streams from the operation of real estate (Boudry et al, 2010).

In our empirical analysis we subdivide non-REITs into firms that provide services comparable to those of REITs (SLOB firms from SIC 651 Real Estate Operators (except Developers) And Lessors) and other real estate firms. We also account for mortgage REITs. To minimise any undue influence of outliers, we winsorise all variables at the 1st and 99th percentiles.

Table 3 presents the Pearson correlation matrix among the measures of all dependent and independent variables for the period of 1973 to 2010. The matrix generally shows low levels of correlation between most independent variables. The definition of the indicator SLOB $=1$ for REITs (except mortgage REITs) and SLOB firms, may have introduced a certain degree of multicollinearity with the REIT indicator. However, the sample correlation is low $(0.3658)$.

\section{Results}

4.1 The interrelationships between leverage and maturity

Table 4 shows the 2SLS results for the REIT and SLOB effects on leverage and maturity. We focus our discussion on the coefficients of the REIT and SLOB indicators and their interactions with leverage and maturity. The control variables outlined in Table 1 are included in the estimation but not shown. Previously observed differences in capital structure choices of REITs and industrial firms seem only partly related to the nature of real estate as the underlying asset class. Its effect appears to be such that neither REITs nor comparable non-REITs determine leverage and maturity simultaneously. However, the drivers of capital structure choices in REITs and non-REITs, and particularly the interdependence between leverage and maturity, differ between the two firm types, reflecting the effects of the REIT status.

For REITs, the coefficient on the interaction term $R E I T^{*} S L O B^{*} M A T$ is significant in the leverage equation, but $R E I T^{*} S L O B^{*} L E V$ is insignificant in the maturity equation. REIT leverage seems negatively related to maturity, but not in reverse. The unidirectional nature of the relationship suggests that REITs determine maturity exogenously and then choose the corresponding leverage. The inverse direction of this relationship contradicts Leland and Toft (1996), a result we examine below. The lack of evidence for simultaneity suggests that REITs use the leverage and maturity dimensions of capital structure for different purposes rather than regarding them as complements or substitutes. We find that non-REIT maturity is positively related to leverage, as the coefficient on the interaction $S L O B^{*} L E V$ is significant in the maturity equation. Non-REITs appear to prioritise the leverage choice and then determine the corresponding debt maturity. The positive sign supports the hypothesis that, for a given level of leverage, non-REITs choose maturity to reduce expected costs of debt in the sense of Alcock et al (2011). Again, non-REITs appear to employ leverage and maturity for different purposes.

We suggest that leverage and maturity may only be chosen simultaneously if the incentives for prioritising the determination of one dimension over the other exactly offset each other. Only in this case would a firm be able to view leverage and maturity as complements or substitutes, depending on other firm-specific characteristics. Our results suggest that nonREITs have an incentive to choose an optimal target level of leverage first, followed by the determination of a corresponding level of maturity.

Regulated REIT firms do not appear to have an a priori preference for a specific debt level, hence optimal maturity is chosen first, and leverage follows. Our results are consistent with the hypothesis that the regulatory and tax situations of a firm influences the incentives for prioritising leverage over maturity choices or vice versa. 
REITs appear to lack an explicit incentive to optimise the amount of leverage. In the absence of corporate tax liabilities, there are no opportunity costs of foregoing tax shield benefits of debt. The costs of inappropriate leverage choices seem less severe than for nonREITs. It appears that the trade-off between marginal tax benefits and marginal direct bankruptcy costs that traditionally is a strong motivator of leverage choices is minimal for REITs. REITs appear to be free from any tax- and bankruptcy cost-related constraints to choosing a certain optimal level of leverage and can hence focus on optimal maturity first. Given that leverage should be of lower importance for REITs, the mitigation of costs associated with sub-optimal levels of maturity is prioritised in the absence of corporate taxation.

Non-REITs seem to have an incentive to optimise the amount of leverage first in order to fully exploit the tax shield benefits of debt. The costs of an inappropriate leverage decision seem more severe than those of a sub-optimal maturity choice. In other words, the costs associated with foregoing some of the tax benefits of debt or, correspondingly, the risk of incurring higher bankruptcy costs, seem to weigh heavier then the costs associated with an inappropriate maturity choice. The consequences of inappropriate maturity, namely higher cost of debt, are not completely ignored. Non-REITs appear to manage the costs of inappropriate maturity, but only subject to an optimal level of leverage. The mitigation of the costs associated with inappropriate levels of leverage appears to be prioritised by firms liable to corporate taxation.

Unlike Giambona et al (2008), we do not find evidence for simultaneity in REIT choices of leverage and maturity. This difference may be due to the fact that we consider REIT status to be a choice variable and adapt our empirical identification strategy to be robust to this additional source of a potential endogeneity bias.

\subsection{The impact of the global financial crisis}

Our empirical results are robust to focussing on the sub-period prior to the global financial crisis. The relationships between leverage and maturity in the two firm types are consistent with those found for the full study period. However, our findings suggest that REITs carried more leverage than comparable unregulated real estate firms in the period 1973-2006. This result is consistent with the anecdotal evidence that REITs typically hold more debt than theory would predict.

During the global financial crisis (2007-2008), the relationships established between leverage and maturity in the two firm types seem to disappear. This finding is consistent with the commonly expressed view that funding liquidity during the global financial crisis reduced sharply. It seems intuitive that the subtle interrelationship between leverage and maturity choices cannot be maintained in an economic climate characterised by severe supply side constraints on funding availability.

Our results also suggest that REITs maintained higher levels of leverage and shorter debt maturities than their unregulated counterparts during the global financial crisis. Our finding is consistent with Barclay and Smith (1995) who argue that regulated firms can borrow longer term debt because they face fewer debt-related agency problems. The regulation of REITs appears to help manage refinancing risk. Our finding also seems intuitively consistent with the view that regulation increases firm transparency and that lenders are especially sensitive to potential agency conflicts with borrowers in an economic situation when funding capacity is restricted.

\subsection{Links to other drivers of capital structure choices}

Table 5 shows the leverage and maturity choices of REITs and non-REITs for the full study period. REITs appear to follow the pecking order to secure the cheapest funds (Feng, Ghosh, and Sirmans, 2007; Giambona et al, 2008). However, firm size carries an unexpected positive sign, suggesting that the lack of transparency in real estate as an asset class (Han, 
2006) generates the asymmetric information that underlies the pecking order theory. This problem is likely to be exacerbated for larger REITs, possibly with a diversified asset base. The information asymmetry resulting from the detailed local market knowledge required to accurately value real estate assets appears to be a strong driver of capital structure in spite of the regulatory pay-out requirement that restricts discretion over retained earnings, normally a crucial assumption of pecking order.

We also find support for the signalling hypothesis, as abnormal earnings carry a positive sign and are highly significant (Howe and Shilling, 1988). REITs seem to signal their quality to the market by issuing more debt when mimicking this strategy is too costly for poorquality firms. Further, REITs seem to employ leverage choices to mitigate growth- and volatility-related agency costs of debt. However, REITs employ only the leverage dimension of capital structure for the mitigation of growth-related agency costs. In contrast, they employ both dimensions to mitigate volatility-related agency costs. Boudry et al (2010) argue that REITs are generally characterised by stable cash flows as they focus on the yield from operations. Earnings volatility seems a strong driver of capital structure choices, as it stands in contrast to the typical REIT business model.

Non-REITs appear to adhere to the trade-off theory, as operating losses carried forward and investment tax credit are significant in the determination of leverage. Consistent with Johnson (2003), the operating losses carried forward dummy has a positive sign. The evidence for the trade-off theory is consistent with the positive relationship we find between leverage and maturity. Further, growth opportunities and highly volatile earnings induce a reduction in non-REIT leverage so as to mitigate agency costs of underinvestment as well as bankruptcy costs and agency costs of debt in the sense of Bradley et al (1984). In line with Harris and Raviv (1990) and Williamson (1988), our findings suggest that non-REITs with higher proportions of tangible assets carry more debt as they tend to have higher liquidation values. Managers respond to perceived investor preferences to use debt to generate information about when liquidation is more lucrative than ongoing operations as well as to monitor management. We find no support for the more offensive signalling theory (Flannery, 1986; Ross, 1977).

REIT maturity choices do not seem to adhere to the asset matching principle. The argument put forward in Kolb (1987) implies that a looser observation of the matching principle indirectly acts as a tool to mitigate refinancing risk. This argument is in line with the finding that REITs do not appear to feel the need to match maturity to their chosen level of leverage so as to (indirectly) reduce refinancing risk. However, we find support for the size- and transaction cost-based theory of debt maturity (Titman and Wessels, 1988). Larger REITs choose maturity so as to exploit economies of scale and optimise transaction costs. This last insight allows us to explain the unusual inverse relationship between REIT maturity and leverage.

If REIT size increases, both maturity and leverage increase, maturity by a transaction cost argument, and leverage by the pecking order argument. So, for a one unit increase in firm size, REITs will eventually hold more debt and this debt is longer term. The increase in maturity is not unwelcome, but in the absence of corporate taxes REITs do not have an incentive to use that much debt (Feng et al, 2007). It appears that REITs aim to benefit from lower transaction costs that result from larger firm size if managers subsequently increase maturity, but limit the increase in leverage resulting from the stronger information asymmetry - a by-product of larger firm size.

The simultaneous increase in leverage and maturity overcorrects the capital structure with regard to what is required to mitigate the information asymmetry resulting from larger firm size. Leverage can then be reduced, conserving the beneficial impact of higher maturity on transaction costs. This strategy is predicated on the lack of any a priori preference for a target debt level of REITs; leverage can be adjusted as a function of a variety of factors. In the Leland and Toft (1996) framework, firm value also depends on bankruptcy costs. For REITs, the reduction in leverage is still in line with their rationale, only that in this particular instance, firm value is maximised by reducing leverage relative to maturity through reducing bankruptcy costs. 
Non-REIT maturity choices appear to be mainly driven by asset-matching and the link to leverage. These two findings are directly related. According to Kolb (1987), a strict observation of the matching principle implies a current ratio of one, thereby increasing refinancing risk during times of limited debt availability. Firms observing the leverage-maturity relationship put forward in Alcock et al (2011) will also benefit from increased protection from credit supply shocks. Firms that are at greatest risk from credit supply shocks are those that are highly levered with substantial short-term debt. If firms with high leverage follow the 'default-risk' theory, they will choose long-term debt and so reduce refinancing risks.

In addition, consistent with a number of single-equation US debt maturity studies, including Barclay and Smith (1995); Datta et al (2005); Johnson (2003) and Billett et al (2007), credit rating is a significant predictor for non-REIT maturity. Non-REITs also appear to employ maturity to mitigate volatility-related agency costs of debt. Overall, real estate companies appear to pursue a rather defensive maturity strategy to ensure funding liquidity and manage refinancing risk as well as agency costs.

Contrary to Hart (1993), non-REIT maturity choices seem positively related to the market-to-book ratio. We interpret this as a direct result of the interaction between leverage and maturity, and it also appears to be the one instance in which we find non-REITs to pursue a more offensive capital structure strategy, albeit indirectly. Consistent with theory and as reported above, we find support for an inverse relationship between non-REIT growth opportunities and leverage so as to mitigate agency costs of underinvestment. However, we also find evidence that, once leverage decreases, non-REITs shorten maturity accordingly so as to reduce expected costs of debt and refinancing risk in the sense of Alcock et al (2011).

Leverage and maturity can be substitutes in the management of the underinvestment problem (Barclay et al, 2003). Given the positive relationship between leverage and maturity, non-REIT capital structure would naturally tend to over-correct maturity with respect to growth opportunities if both dimensions of capital structure were to be reduced. If this overcorrection is allowed to run its course, firms find themselves with low levels of leverage but also with unnecessarily short maturities. There are two main risks surrounding unnecessarily short maturities, refinancing risk (the risk of not obtaining new funding) and transaction costs involved in sourcing new funding. Refinancing risk is mitigated through the leveragematurity relationship. Non-REITs only use short-maturity debt if their leverage levels are sufficiently low. Therefore, given that refinancing risk is controlled, non-REITs have an opportunity here to indirectly reduce transaction costs in the sense of Titman and Wessels (1988) by swapping short-term debt for equity.

Overall, the capital structure choices of REITs appear to be more offensive than those of non-REITs as the regulatory setting renders the mitigation of corporate taxation obsolete, reduces agency conflicts, helps manage refinancing risk and thus frees up flexibility in the capital structure to signal firm quality and optimise transaction costs. This interpretation is consistent with Alcock, Glascock, and Steiner (2012) who argue that REITs opportunistically employ leverage to enhance performance measures. Our results suggest that the relationship between leverage and maturity can also be used to moderate the effects of exogenous financing policies.

\section{Summary and conclusion}

In this study, we focus on the joint determination of leverage and maturity in real estate firms. Previous research indicates substantial differences in the relationship between leverage and maturity for REITs versus industrial firms. We compare the capital structure choices of REITs and non-REITs so as to contrast the effects of real estate as the underlying asset class versus those of regulation and taxation.

We find that the difference in capital structure choices between REITs and industrial firms is only partly due to the underlying asset class. The effects of the REIT regulation have a significant impact on capital structure choices. Further, we find that simultaneous determination of leverage and maturity may only be possible when the incentives to prioritise the choice of one dimension over the other exactly offset each other. In the presence of 
corporate taxation, non-REITs prioritise the choice of an optimal target level of leverage. For REITs, there is no incentive to prioritise the leverage choice, so they appear to focus on maturity. Our results also suggest that, in addition to the interpretation of leverage and maturity as substitutes or complements, the relationship between the two dimensions of capital structure can also be used to moderate the effects of other exogenous financing policies.

Overall, REITs seem to use the leverage dimension of capital structure to follow the pecking order and secure cheaper funds, to actively signal firm quality and to mitigate growth- and especially volatility-related agency costs. Equity-related agency costs explain the inverse relationship between leverage and maturity. REIT maturity choices appear to be mainly targeted at mitigating underinvestment problems and exploiting economies of scale. Unregulated real estate companies on the other hand have a higher exposure to debt-related agency costs and are therefore more defensive in their capital structure. In line with the tradeoff theory, they focus on the mitigation of corporate taxes, which implies that they prioritise the choice of a target level of leverage. This finding is consistent with the positive relationship we confirm between leverage and maturity. Non-REITs appear to largely tailor their capital structure choices to the timely provision of funding for new projects, the management of debt-related agency costs and the reduction of refinancing risk for a chosen level of leverage.

Howe and Shilling (1988) argue that REITs cannot compete for debt as they cannot benefit from the tax shields offered by interest payments. It has long puzzled researchers why REITs still use debt, and in some cases substantially higher leverage ratios than unregulated real estate companies. Our findings suggest that the regulatory setting and tax-exempt status of REITs provides sufficient flexibility in the capital structure to exploit the benefits of a more offensive financing strategy and to offset the comparatively higher net cost of debt.

\section{References}

Alcock J, Finn F, Tan KJK (2011) The determinants of debt maturity in australian firms. Accounting \& Finance DOI 10.1111/j.1467-629X.2010.00397.x, URL http://dx.doi.org/ 10.1111/j.1467-629X.2010.00397.x

Alcock J, Glascock JL, Steiner E (2012) Manipulation in u.s. reit investment performance evaluation: Empirical evidence. Journal of Real Estate Finance and Economics Forthcoming

Ashenfelter O, Card D (1985) Using the longitudinal structure of earnings to estimate the effect of training programs. The Review of Economics and Statistics 67(4):pp. 648-660, URL http://www. jstor.org/stable/1924810

Barclay MJ, Smith C (1995) The maturity structure of corporate debt. Journal of Finance 50(2):609-631, URL http://www.jstor .org/stable/pdfplus/2329421.pdf

Barclay MJ, Marx LM, Smith CW (2003) The joint determination of leverage and maturity. Journal of Corporate Finance 9(2):149-167

Bertrand M, Mullainathan S (2003) Enjoying the quiet life? corporate governance and managerial preferences. Journal of Political Economy 111(5):pp. 1043-1075, URL http: //www.jstor.org/stable/10.1086/376950

Billett MT, King THD, Mauer DC (2007) Growth opportunities and the choice of leverage, debt maturity, and covenants. The Journal of Finance 62(2):697-730, URL http://www . afajof .org/afa/forthcoming/2392.pdf

Boudry WI, Kallberg JG, Liu CH (2010) An analysis of reit security issuance decisions. Real Estate Economics 38(1):91-120

Bradley M, Jarrell G, Kim E (1984) On the existence of an optimal capital structure: theory and evidence. Journal of Finance 39(3):857-878, URL http://www. jstor .org/stable/ pdfplus/2327950.pdf

Brounen D, Eichholtz PMA (2001) Capital structure theory: Evidence from european property companies. Real Estate Economics 29:615-632, URL http://arno.unimaas.nl/ show.cgi?fid=10693 
Brown DT, Riddiough TJ (2003) Financing choice and liability structure of real estate investment trusts. Real Estate Economics 31(3):313-346

Card D, Krueger AB (1994) Minimum wages and employment: A case study of the fastfood industry in new jersey and pennsylvania. The American Economic Review 84(4):pp. 772-793, URL http://www.jstor.org/stable/2118030

Datta S, Iskandar-Datta M, Raman (2005) Managerial stock ownership and the maturity structure of corporate debt. The Journal of Finance 60(5):2333-2350

DeAngelo H, Masulis R (1980) Optimal capital structure under corporate and personal taxation. Journal of Financial Economics 8(1):3-29, URL http://www. sciencedirect . com/science/article/B6VBX-45N501G-3J/2/379d61af946c024bd1acdf186aadd663

Diamond D (1991) Debt maturity structure and liquidity risk. Quarterly Journal of Economics 106:709-737

Donaldson G (1961) Corporate debt capacity: a study of corporate debt policy. Harvard Graduate School of Business

Feng Z, Ghosh C, Sirmans C (2007) On the capital structure of real estate investment trusts (reits). Journal of Real Estate Finance and Economics 34:81-105

Flannery MJ (1986) Asymmetric information and risky debt maturity choice. Journal of Finance 41(1):19-37

Ghosh C, Nag R, Sirmans C (1997) Financing choice by equity reits in the 1990s. Real Estate Economics 14(3):41-50, URL http://www.business.uconn.edu/Realestate/ publications/pdf $\% 20$ documents/221\%20REITs $\% 20$ int $\% 20$ he $\% 2090$ s $\% 20$ REF $\% 20$ Fall 97 . $\operatorname{pdf}$

Ghosh C, Nag R, Sirmans C (1999) An analysis of seasoned equity offerings by equity reits, 1991 to 1995. Journal of Real Estate Finance and Economics 19:175-192

Ghosh C, Nag R, Sirmans C (2000) A test of the signaling value of ipo underpricing with reit ipo-seo pairs. The Journal of Real Estate Finance and Economics 20:137-154

Giambona E, Harding JP, Sirmans C (2008) Explaining the variation in reit capital structure: the role of asset liquidation value. Real Estate Economics 36(1):111 - 137, URL http://web.ebscohost.com/ehost/pdf?vid=2\&hid=108\&sid= 5ef7d2ac-05b1-4e4f-af 10-a19f 831 dde $7 f \% 40$ sessionmgr 104

Greene WH (2002) Econometric analysis. Prentice Hall, Englewood Cliffs, NJ.

Han B (2006) Inside ownership and firm value: Evidence from real estate investment trusts. The Journal of Real Estate Finance and Economics 32:471-493

Harris M, Raviv A (1990) Capital structure and the informational role of debt. Journal of Finance 45(2):321-349

Hart O (1993) Theories of Optimal Capital Structure: A Managerial Discretion Perspective. Washington, DC: The Brookings Institution

Highfield MJ, Roskelley KD, Zhao F (2007) The determinants of the debt maturity decision for real estate investment trusts. Journal of Real Estate Research 29(2):173-199

Hong HG, Kubik JD, Scheinkman JA (2011) Financial constraints on corporate goodness. SSRN eLibrary DOI 10.2139/ssrn.1734164

Howe J, Shilling J (1988) Capital structure theory and reit security offerings. The Journal of Finance 43:983-993

Jensen MC (1986) Agency costs of free cash flow, corporate finance, and takeovers. The American Economics Review 76(2):323-329, URL http://www . jstor.org/stable/ pdfplus/1818789.pdf

Johnson SA (2003) Debt maturity and the effects of growth opportunities and liquidity risk on leverage. Review of Financial Studies 16(1):209-236

Kolb R (1987) Financial management. Glenview: Scott Foresman and Company

Kraus A, Litzenberger RH (1973) A state-preference model of optimal financial leverage. The Journal of Finance 28(4):911-922, URL http://www . jstor . org/stable/2978343

Leland H, Toft K (1996) Optimal capital structure, endogenous bankruptcy, and the term structure of credit spreads. Journal of Finance 51(3):987-1019

Modigliani F, Miller M (1963) Corporate income taxes and the cost of capital: a correction. American Economic Review 53(3):433-443, URL http://www. jstor.org/stable/ pdfplus/1809167.pdf 
Myers S (1984) The capital structure puzzle. Journal of Finance 39(3):575-592, URL http: //www.jstor.org/stable/pdfplus/2327916.pdf

Myers S, Majluf N (1984) Corporate financing and investment decisions when firms have information that investors do not have. Journal of Financial Economics 13(2):187221, URL http://www.sciencedirect.com/science/article/B6VBX-45KRNOW-5K/1/ 7766bb220cfef06097c70fd17fffa9ad

Roberts MR, Whited TM (2011) Endogeneity in empirical corporate finance. SSRN eLibrary DOI 10.2139/ssrn.1748604

Ross SA (1977) The determination of financial structure: the incentive-signalling approach. The Bell Journal of Economics 8(1):23-40, URL http://www.ecsocman.edu.ru/images/ pubs/2007/10/25/0000314521/ross___signaling_1977.pdf

Scherr FC, Hulburt HM (2001) The debt maturity structure of small firms. Financial Management 30(1):85-111

Sharpe S (1991) Credit rationing, concessionary lending and debt maturity structure. Journal of Banking and Business 15(3):581-604, URL http://www. sciencedirect.com/ science/article/B6VCY-45FCJK9-7/1/6779b6dbb045b78a6b65c74168985cd5

Shilling JD (1994) Taxes and the capital structure of partnerships, reits, and other related entities. Working Paper, University of Wisconsin

Shyam-Sunder L, Myers S (1999) Testing static tradeoff against pecking order models of capital structure. Journal of Financial Economics 51(2):219-244, DOI doi:10.1016/ S0304-405X(98)00051-8

Stohs M, Mauer DC (1996) The determinants of corporate debt maturity structure. Journal of Business 69(3):279-312

Titman S (1992) Interest rate swaps and corporate financing choices. Journal of Finance 47:1503-1516

Titman S, Wessels R (1988) Determinants of capital structure. Journal of Finance 43(1):1-19

Williamson OE (1988) Corporate finance and corporate governance. The Journal of Finance 43(3):567-591, URL http://www. jstor.org/stable/2328184?cookieSet=1 


\section{Figures and Tables}

Control variables and proxies

\begin{tabular}{|c|c|c|}
\hline $\begin{array}{l}\text { Proxies for leverage hypothe- } \\
\text { ses }\end{array}$ & Theory & Reference \\
\hline $\begin{array}{l}\text { Maturity (share of total debt ma- } \\
\text { turing in more than } 3 \text { years) }\end{array}$ & $\begin{array}{l}\text { Maturity determines leverage to } \\
\text { maximise firm value }\end{array}$ & Leland and Toft, 1996 \\
\hline $\begin{array}{l}\text { Alternative tax shields (dummies } \\
\text { for tax credits and loss carry for- } \\
\text { ward, } 1 \text { in presence of alternative } \\
\text { tax shield) }\end{array}$ & Trade-off theory & DeAngelo and Masulis, 1980 \\
\hline $\begin{array}{l}\text { Growth opportunities (market to } \\
\text { book) }\end{array}$ & $\begin{array}{l}\text { Mitigate agency costs of underin- } \\
\text { vestment }\end{array}$ & Myers, 1977 \\
\hline $\begin{array}{l}\text { Firm size (log of market value of } \\
\text { the firm) }\end{array}$ & $\begin{array}{l}\text { Static pecking order (information } \\
\text { asymmetry) }\end{array}$ & Myers and Majluf, 1984 \\
\hline $\begin{array}{l}\text { Profitability (EBITDA to book } \\
\text { value of assets) }\end{array}$ & Dynamic pecking order & $\begin{array}{l}\text { Donaldson, 1961; Myers and Ma- } \\
\text { jluf, } 1984\end{array}$ \\
\hline Firm quality (abnormal earnings) & Signalling & Ross, 1977 \\
\hline $\begin{array}{l}\text { Fixed assets ratio (NPPE to book } \\
\text { value of assets) }\end{array}$ & Information extraction & $\begin{array}{l}\text { Harris and Raviv, 1990; } \\
\text { Williamson, } 1988\end{array}$ \\
\hline $\begin{array}{l}\text { Volatility of earnings (stdev. of 1st } \\
\text { diff. in EBITDA over } 4 \text { yrs.) }\end{array}$ & Credit risk & Bradley, Jarrell and Kim, 1984 \\
\hline $\begin{array}{l}\text { Proxies for maturity hypothe- } \\
\text { ses }\end{array}$ & Theory & Reference \\
\hline $\begin{array}{l}\text { Leverage (total debt to market } \\
\text { value of assets) }\end{array}$ & $\begin{array}{l}\text { Leverage determines maturity to } \\
\text { reduce costs of default and refi- } \\
\text { nancing risk }\end{array}$ & Alcock, Finn and Tan, 2010 \\
\hline $\begin{array}{l}\text { Asset maturity (log of gross depre- } \\
\text { ciable property to depreciation ex- } \\
\text { pense) }\end{array}$ & Asset-matching principle & Myers, 1977 \\
\hline $\begin{array}{l}\text { Growth opportunities (market to } \\
\text { book) }\end{array}$ & $\begin{array}{l}\text { Mitigate agency costs of underin- } \\
\text { vestment }\end{array}$ & Hart, 1993 \\
\hline Firm quality (abnormal earnings) & Signalling & Flannery, 1986 \\
\hline $\begin{array}{l}\text { Firm size (log of market value of } \\
\text { the firm) }\end{array}$ & Transaction costs & Titman and Wessels, 1988 \\
\hline $\begin{array}{l}\text { Volatility of earnings (stdev. of 1st } \\
\text { diff. in EBITDA over } 4 \text { yrs.) }\end{array}$ & Credit risk & Bradley, Jarrell and Kim, 1984 \\
\hline $\begin{array}{l}\text { Debt rating (dummy, } 1 \text { in presence } \\
\text { of debt rating) }\end{array}$ & Liquidity risk & $\begin{array}{l}\text { Diamond, 1991; Sharpe, 1991; Tit- } \\
\text { man, } 1992\end{array}$ \\
\hline $\begin{array}{l}\text { Term structure (10-yr. vs. } 6 \text {-month } \\
\text { government bond) }\end{array}$ & Tax benefits & Brick and Ravid, 1985 \\
\hline
\end{tabular}

Table 1 The table shows the control variables and their proxies/measurements included in our study. Bond yields have been obtained from the Federal Reserve Bank of St. Louis's Economic Database. We include year dummy variables in the debt maturity regression to control for the effects of latent macroeconomic event shock factors. 


\begin{tabular}{|c|c|c|c|c|c|c|c|}
\hline Characteristic & Mean & $\begin{array}{l}\text { Std. } \\
\text { Dev. }\end{array}$ & $\operatorname{Min}$ & 25 th & 50th & 75th & Max \\
\hline $\begin{array}{l}\text { Firm Value (\$mil) } \\
\text { Debt Maturity }\end{array}$ & $\begin{array}{l}1822 * * * \\
0.61 * * *\end{array}$ & $\begin{array}{c}3,153 \\
0.29\end{array}$ & $\begin{array}{l}3.70 \\
0.00\end{array}$ & $\begin{array}{l}99.35 \\
0.44\end{array}$ & $\begin{array}{c}389.63 \\
0.68\end{array}$ & $\begin{array}{l}1972 \\
0.85\end{array}$ & $\begin{array}{c}18837 \\
0.99\end{array}$ \\
\hline $\begin{array}{l}\text { Leverage } \\
\text { Log of Asset Maturity } \\
\text { Market-to-book }\end{array}$ & $\begin{array}{l}0.4 .15 * * * \\
3.126 *\end{array}$ & $\begin{array}{l}0.23 \\
0.95\end{array}$ & $\begin{array}{l}0.01 \\
0.33\end{array}$ & $\begin{array}{l}0.28 \\
2.87\end{array}$ & $\begin{array}{l}0.44 \\
3.18 \\
3.18\end{array}$ & $\begin{array}{l}0.60 \\
3.79 \\
3.79\end{array}$ & $\begin{array}{l}0.93 \\
5.16\end{array}$ \\
\hline $\begin{array}{l}\text { bunormal Earnings } \\
\text { Logof For Firm Value }\end{array}$ & $\begin{array}{l}0.15 \\
6.03 * * *\end{array}$ & $\begin{array}{l}0.85 \\
1.95 \\
1.95\end{array}$ & $\begin{array}{l}-1.16 \\
1.93 \\
\end{array}$ & $\begin{array}{l}-0.03 \\
4.45\end{array}$ & $\begin{array}{l}0.01 \\
0.99\end{array}$ & $\begin{array}{l}0.05 \\
7.58\end{array}$ & $\begin{array}{l}5.66 \\
9.82\end{array}$ \\
\hline $\begin{array}{l}\text { Earnings Volatilitity } \\
\text { Term Structure }\end{array}$ & $\begin{array}{l}0.04 * * \\
1.57\end{array}$ & $\begin{array}{l}0.04 \\
1.23\end{array}$ & $\begin{array}{l}0.00 \\
-0.1 .39 \\
-1.39\end{array}$ & $\begin{array}{l}0.01 \\
0.83\end{array}$ & $\begin{array}{l}0.02 \\
1.65\end{array}$ & $\begin{array}{l}0.05 \\
2.58\end{array}$ & $\begin{array}{l}0.25 \\
3.42\end{array}$ \\
\hline $\begin{array}{l}\text { Fied Asset Ratio } \\
\text { Profitability }\end{array}$ & $0.50^{0 * *}$ & $\begin{array}{l}0.29 \\
0.06\end{array}$ & & $\begin{array}{l}0.39 \\
0.04\end{array}$ & $\begin{array}{l}0.63 \\
0.09\end{array}$ & $\begin{array}{l}0.80 \\
0.11\end{array}$ & \\
\hline $\begin{array}{l}\text { Operating Loss Carryforwards } \\
\text { Investment Tax Credit }\end{array}$ & $\begin{array}{l}0.18 * * \\
0.23\end{array}$ & $\begin{array}{l}0.38 \\
0.42\end{array}$ & & & & & \\
\hline
\end{tabular}

\begin{tabular}{|c|c|c|c|c|c|c|c|}
\hline & & & & ristic & & & \\
\hline Characteristic & Mean & $\begin{array}{l}\text { Std. } \\
\text { Dev. }\end{array}$ & Min & 25th & 50th & 75th & $\operatorname{Max}$ \\
\hline & $\begin{array}{l}701 \\
0.49\end{array}$ & $\begin{array}{l}2,202 \\
0.30\end{array}$ & $\begin{array}{l}0.63 \\
0.00\end{array}$ & $\begin{array}{l}23.98 \\
0.22\end{array}$ & & $\begin{array}{l}320 \\
0.77\end{array}$ & $\begin{array}{l}25002 \\
0.99\end{array}$ \\
\hline \multirow{2}{*}{$\begin{array}{l}\text { Log of Asset Maturity } \\
\text { Marke-t-to-book } \\
\text { Abnormal Earnings }\end{array}$} & $\begin{array}{l}0.41 \\
2.99 \\
1.31\end{array}$ & $\begin{array}{l}0.23 \\
0.93 \\
0.78\end{array}$ & $\begin{array}{l}0.01 \\
0.53 \\
0.56\end{array}$ & $\begin{array}{l}0.24 \\
2.39 \\
0.91\end{array}$ & $\begin{array}{l}0.41 \\
3.10 \\
1.05\end{array}$ & $\begin{array}{l}0.58 \\
3.56 \\
1.39\end{array}$ & $\begin{array}{l}0.86 \\
5.38 \\
5.14\end{array}$ \\
\hline & $\begin{array}{l}1.31 \\
0.04\end{array}$ & $\begin{array}{l}0.78 \\
0.78 \\
0.78\end{array}$ & $\begin{array}{l}0.56 \\
-3.12 \\
-3.12 \\
\end{array}$ & $\begin{array}{l}0.91 \\
-0.07\end{array}$ & $\begin{array}{l}1.05 \\
0.01\end{array}$ & $\begin{array}{l}1.39 \\
0.07\end{array}$ & $\begin{array}{l}5.14 \\
5.04\end{array}$ \\
\hline $\begin{array}{l}\text { Log of Firm Value } \\
\text { Earnings Volatility }\end{array}$ & $\begin{array}{l}0.06 \\
1.48\end{array}$ & $\begin{array}{l}0.07 \\
1.29\end{array}$ & $\begin{array}{l}0.00 \\
-180\end{array}$ & $\begin{array}{l}0.02 \\
0.58 \\
0.58\end{array}$ & $\begin{array}{l}0.04 \\
162 \\
162\end{array}$ & $\begin{array}{l}0.07 \\
2.53\end{array}$ & 0.37 \\
\hline $\begin{array}{l}\text { Termm Strucuture } \\
\text { Fixed Asset redio } \\
\text { Profitabilitity }\end{array}$ & $\begin{array}{l}0.37 \\
0.07\end{array}$ & $\begin{array}{l}0.29 \\
0.10\end{array}$ & $\begin{array}{l}0.00 \\
-0.27 \\
-0.00\end{array}$ & $\begin{array}{l}0.08 \\
0.03\end{array}$ & $\begin{array}{l}0.31 \\
0.08\end{array}$ & $\begin{array}{l}0.63 \\
0.13\end{array}$ & \\
\hline $\begin{array}{l}\text { roportion of firm-years with } \\
\text { Operating Loss Carryforwards }\end{array}$ & 0.28 & 0.45 & & & & & \\
\hline $\begin{array}{l}\text { Investment IT } \\
\text { Debt Rating }\end{array}$ & $\begin{array}{l}0.15 \\
0.12\end{array}$ & $\begin{array}{l}0.36 \\
0.33\end{array}$ & & & & & \\
\hline
\end{tabular}

Table 2 The table reports distribution of corporate debt maturity in Panel A (Panel C) and descriptive statistics in Panel B (Panel D) for 1385 firm-year observations of Real Estate Investment Trusts, REIT, and (Non-REIT) between 1973 and 2011 from Compustat Database, respectively. Non-REITs are firms with Standard Industrial Classification (SIC) codes from 6500 to 6552. Variables are defined as: Debt Maturity is measured by the proportion of debt maturity due in more than three years. Leverage is the ratio of total debt (long-term debt plus debt in current liabilities) to market value of assets, where market value of assets is estimated as book value of total assets less book value of common equity plus market value of common equity. Log of Asset Maturity is measured by the natural logarithm of the ratio of depreciable assets to depreciation. Market-to-book is measured by the market value of assets divided by the book value of assets.
Abnormal Earnings is the difference between earning per share in year $t+1$ minus earnings per share in year $t$, divided by the year $t$ share price. Log of Firm Size is measured by the natural Abnormal Earnings is the difference between earning per share in year $t+1$ minus earnings per share in year $t$, divided by the year $t$ share price. Log of Firm Size is measured by the natural
logarithm of the market firm value in millions of dollars. Dollar values are inflation-adjusted (June 1982) using the the Producer Price Index (PPI). Earnings Volatility is measured by the logarithm of the market firm value in millions of dollars. Dollar values are inflation-adjusted (June 1982) using the the Producer Price Index (PPI). Earnings Volatility is measured by the standard deviation of first differences in EBITDA over the four years preceding the sample year, scaled by average assets for that period. Term Structure is the difference between the month-end yields on a le means of REITs indicate whether they are significantly different from those of non-REITs. ******** indicate significance at the $5 \%$ level, $1 \%$ level and $0.1 \%$ level, respectively. 
Pearson Correlation Matrix Among Measures of Dependent and Independent Variables for all firms

\begin{tabular}{|c|c|c|c|c|c|c|c|c|c|c|c|c|c|c|c|}
\hline 1) $\mathrm{D}-\mathrm{s}+\mathrm{C}$ & (1) & $(2)$ & $(3)$ & $(4)$ & $(5)$ & $(6)$ & $(7)$ & $(8)$ & (9) & $(10)$ & $(11)$ & $(12)$ & $(13)$ & $(14)$ & $(15)$ \\
\hline (1) Debt Maturity & $\begin{array}{c}1 \\
0.04\end{array}$ & & & & & & & & & & & & & & \\
\hline $\begin{array}{l}\text { (2) Leverage } \\
\text { (3) SLOB }\end{array}$ & $0.20^{* * *}$ & $\begin{array}{c}1 \\
0.02\end{array}$ & 1 & & & & & & & & & & & & \\
\hline (4) REITs & $0.14^{* * *}$ & $0.05^{*}$ & $0.37^{* * *}$ & 1 & & & & & & & & & & & \\
\hline (5) Asset Maturity & $0.08^{* *}$ & $0.06^{*}$ & $0.24^{* * *}$ & $0.08^{* *}$ & 1 & & & & & & & & & & \\
\hline (6) Market/book & $0.08^{* *}$ & $-0.43^{* * *}$ & $0.12^{* * *}$ & -0.01 & 0.03 & 1 & & & & & & & & & \\
\hline (7) Abnorm. Earn. & $-0.05^{*}$ & $0.08^{* * *}$ & -0.03 & 0.03 & -0.04 & -0.04 & 1 & & & & & & & & \\
\hline (8) Firm Size & $0.24^{* * *}$ & -0.01 & $-0.10^{* * *}$ & $0.22^{* * *}$ & $-0.19 * * *$ & $0.15^{* * *}$ & 0.02 & 1 & & & & & & & \\
\hline (9) Volatility & $-0.16^{* * *}$ & $-0.14^{* * *}$ & $-0.10^{* * *}$ & $-0.10^{* * *}$ & $-0.11^{* * *}$ & $0.07^{* *}$ & $0.07^{* *}$ & $-0.23 * * *$ & 1 & & & & & & \\
\hline (10) Term Struct. & -0.02 & -0.05 & 0.01 & 0.02 & -0.03 & 0.02 & 0.01 & 0.02 & 0.04 & 1 & & & & & \\
\hline (11) Fixed Assets & $0.23 * * *$ & $0.08^{* *}$ & $0.56^{* * *}$ & $0.22 * * *$ & $0.59^{* * *}$ & $0.09^{* * *}$ & 0 & $-0.10^{* * *}$ & $-0.14^{* * *}$ & 0.03 & 1 & & & & \\
\hline (12) Profitability & $0.10^{* * *}$ & $-0.12^{* * *}$ & 0.03 & 0.03 & -0.03 & $0.07^{* *}$ & $-0.12 * * *$ & $0.07^{* *}$ & $-0.21^{* * *}$ & $-0.08^{* *}$ & $0.11^{* * *}$ & 1 & & & \\
\hline (13) Loss Carryfwd. & $-0.10 * * *$ & $0.14^{* * *}$ & $-0.12^{* * *}$ & $-0.08^{* *}$ & -0.03 & $-0.05^{*}$ & 0.04 & $-0.11^{* * *}$ & $0.13^{* * *}$ & 0.03 & $-0.13^{* * *}$ & $-0.18^{* * *}$ & 1 & & \\
\hline (14) Tax Credit & 0.02 & $-0.11 * * *$ & $0.10^{* * *}$ & $0.07^{* *}$ & 0.02 & $-0.07^{* *}$ & -0.03 & $-0.13^{* * *}$ & $-0.10^{* * *}$ & $-0.09^{* * *}$ & $0.06^{*}$ & $0.10^{* * *}$ & $-0.17^{* * *}$ & 1 & \\
\hline (15) Debt Rating & $0.17^{* * *}$ & 0.03 & $-0.13^{* * *}$ & $0.09^{* * *}$ & $-0.31 * * *$ & -0.01 & $0.09^{* * *}$ & $0.57^{* * *}$ & -0.03 & 0.02 & $-0.24^{* * *}$ & -0.01 & 0.04 & $-0.13^{* * *}$ & 1 \\
\hline
\end{tabular}
Table 3 The table reports Pearson correlation among dependent and independent variables of leverage and debt maturity for 201 firm-year observations for REITs between 1973 and 2011 from
Compustat Database. All variables are defined in Table $2 .^{*},{ }^{* *},{ }^{* * * *}$ indicate significance at the $5 \%$ level, $1 \%$ level and $0.1 \%$ level, respectively. 
2SLS Regression results for REIT and SLOB effects

\begin{tabular}{|c|c|c|c|c|c|c|}
\hline \multirow{4}{*}{$\begin{array}{l}\text { VARIABLES } \\
\text { SLOB }\end{array}$} & \multicolumn{6}{|c|}{ REIT effect on joint leverage and maturity choice } \\
\hline & \multicolumn{2}{|c|}{$\overline{1973-2006}$} & \multicolumn{2}{|c|}{$\overline{1973-2011}$} & \multicolumn{2}{|c|}{$2007-2008$} \\
\hline & Leverage & Maturity & Leverage & Maturity & Leverage & Maturity \\
\hline & $\begin{array}{l}0.002 \\
(0.02)\end{array}$ & $\begin{array}{c}0.139^{* * *} \\
(0.04)\end{array}$ & $\begin{array}{l}-0.009 \\
(0.02)\end{array}$ & $\begin{array}{c}0.130^{* * *} \\
(0.03)\end{array}$ & $\begin{array}{l}0.082 \\
(0.08)\end{array}$ & $\begin{array}{c}-0.016 \\
(0.12)\end{array}$ \\
\hline REIT & $\begin{array}{l}0.141 \\
(0.08)\end{array}$ & $\begin{array}{c}-0.098 \\
(0.09)\end{array}$ & $\begin{array}{l}0.173^{*} \\
(0.07)\end{array}$ & $\begin{array}{r}-0.068 \\
(0.07)\end{array}$ & $\begin{array}{c}0.458^{* *} \\
(0.16)\end{array}$ & $\begin{array}{c}-0.644^{*} \\
(0.30)\end{array}$ \\
\hline Market Leverage & & $\begin{array}{l}-0.187 \\
(0.25)\end{array}$ & & $\begin{array}{r}-0.022 \\
(0.23)\end{array}$ & & $\begin{array}{l}0.761 \\
(0.43)\end{array}$ \\
\hline SLOB_REIT_LEV & & $\begin{array}{l}0.303 \\
(0.22)\end{array}$ & & $\begin{array}{l}0.217 \\
(0.18)\end{array}$ & & $\begin{array}{l}0.839 \\
(0.49)\end{array}$ \\
\hline Debt Maturity & $\begin{array}{l}0.096 \\
(0.10)\end{array}$ & & $\begin{array}{l}0.065 \\
(0.09)\end{array}$ & & $\begin{array}{l}0.275 \\
(0.31)\end{array}$ & \\
\hline SLOB_REIT_MAT & $\begin{array}{c}-0.280^{*} \\
(0.12)\end{array}$ & & $\begin{array}{c}-0.288^{* *} \\
(0.10)\end{array}$ & & $\begin{array}{l}-0.213 \\
(0.35)\end{array}$ & \\
\hline Observations & 1,459 & 1,459 & 1,586 & 1,586 & 80 & 80 \\
\hline
\end{tabular}

\begin{tabular}{|c|c|c|c|c|c|c|}
\hline \multirow{3}{*}{$\begin{array}{l}\text { Panel B } \\
\text { VARIABLES }\end{array}$} & \multicolumn{6}{|c|}{ SLOB effect on joint leverage and maturity choice } \\
\hline & \multicolumn{2}{|c|}{$1973-2006$} & \multicolumn{2}{|c|}{$1973-2011$} & \multicolumn{2}{|c|}{$2007-2008$} \\
\hline & Leverage & Maturity & Leverage & Maturity & Leverage & Maturity \\
\hline SLOB & $\begin{array}{c}-0.013 \\
(0.05)\end{array}$ & $\begin{array}{c}-0.276^{* * *} \\
(0.07)\end{array}$ & $\begin{array}{c}-0.061 \\
(0.05)\end{array}$ & $\begin{array}{c}-0.221^{* * *} \\
(0.06)\end{array}$ & $\begin{array}{c}-0.256 \\
(0.50)\end{array}$ & $\begin{array}{l}-0.043 \\
(0.17)\end{array}$ \\
\hline Market Leverage & & $\begin{array}{c}-0.734^{* * *} \\
(0.20)\end{array}$ & & $\begin{array}{c}-0.544^{* *} \\
(0.17)\end{array}$ & & $\begin{array}{c}-0.080 \\
(0.33)\end{array}$ \\
\hline SLOB_LEV & & $\begin{array}{c}0.970 * * * \\
(0.18)\end{array}$ & & $\begin{array}{c}0.814^{* * *} * \\
(0.16)\end{array}$ & & $\begin{array}{l}0.249 \\
(0.33)\end{array}$ \\
\hline Debt Maturity 3 & $\begin{array}{l}0.055 \\
(0.10)\end{array}$ & & $\begin{array}{c}-0.008 \\
(0.09)\end{array}$ & & $\begin{array}{c}-0.521 \\
(0.88)\end{array}$ & \\
\hline SLOB_MAT & $\begin{array}{r}0.033 \\
(0.10) \\
\end{array}$ & & $\begin{array}{l}0.115 \\
(0.10) \\
\end{array}$ & & $\begin{array}{r}0.618 \\
(0.81) \\
\end{array}$ & \\
\hline Observations & 1,270 & 1,270 & 1,385 & 1,385 & 72 & 72 \\
\hline
\end{tabular}

Table 4 The table shows the two-stage least squares regression results with the coefficients for the main explanatory variables of interest over the three periods considered. The control variables outlined in Table 1 are included in the estimation but the coefficients are not shown in the table since the discussion focuses on the REIT and SLOB indicators and their interactions with leverage and maturity. Robust (clustered by firm) standard errors are reported in parentheses. Year dummies are included in the maturity regression to capture latent changes in the general economic environment. Significance is denoted as: $* * * \mathrm{p}<0.001,{ }^{*} \mathrm{p}<0.01, * \mathrm{p}<0.05$. 
2SLS Regression results for firm types separately

\begin{tabular}{|c|c|c|c|c|}
\hline \multirow{2}{*}{$\begin{array}{l}1973-2011 \\
\text { Variables }\end{array}$} & \multicolumn{2}{|c|}{ REITs } & \multicolumn{2}{|c|}{ Non-REITs } \\
\hline & Leverage & Maturity & Leverage & Maturity \\
\hline Market Leverage & & $\begin{array}{l}0.102 \\
(0.23)\end{array}$ & & $\begin{array}{l}0.299^{*} \\
(0.15)\end{array}$ \\
\hline Debt Maturity & $\begin{array}{c}-0.218^{*} \\
(0.11)\end{array}$ & & $\begin{array}{l}0.006 \\
(0.08)\end{array}$ & \\
\hline Asset Maturity & & $\begin{array}{c}0.012 \\
(0.02)\end{array}$ & & $\begin{array}{c}0.029 * * \\
(0.01)\end{array}$ \\
\hline Market-to-book & $\begin{array}{c}-0.133^{* *} \\
(0.04)\end{array}$ & $\begin{array}{l}0.097 \\
(0.06)\end{array}$ & $\begin{array}{c}-0.136^{* * *} \\
(0.01)\end{array}$ & $\begin{array}{c}0.063^{* *} \\
(0.02)\end{array}$ \\
\hline Abnormal Earnings & $\begin{array}{c}0.084^{* * * *} \\
(0.02)\end{array}$ & $\begin{array}{r}-0.036 \\
(0.03)\end{array}$ & $\begin{array}{l}0.004 \\
(0.01)\end{array}$ & $\begin{array}{c}-0.016 \\
(0.01)\end{array}$ \\
\hline Log of Firm Value & $\begin{array}{c}0.029^{* *} \\
(0.01)\end{array}$ & $\begin{array}{c}0.056^{* * * *} \\
(0.01)\end{array}$ & $\begin{array}{l}0.005 \\
(0.01)\end{array}$ & $\begin{array}{l}0.011 \\
(0.01)\end{array}$ \\
\hline Volatility & $\begin{array}{c}-1.045^{* *} \\
(0.40)\end{array}$ & $\begin{array}{c}-1.202^{* *} \\
(0.43)\end{array}$ & $\begin{array}{c}-0.456^{* * *} \\
(0.11)\end{array}$ & $\begin{array}{c}-0.360^{*} \\
(0.14)\end{array}$ \\
\hline Term Structure & & $\begin{array}{c}0.01 \\
(0.03)\end{array}$ & & $\begin{array}{c}-0.009 \\
(0.02)\end{array}$ \\
\hline Debt Rated & & $\begin{array}{c}0.109^{*} \\
(0.05)\end{array}$ & & $\begin{array}{c}0.101^{* *} * \\
(0.03)\end{array}$ \\
\hline Fixed Assets Ratio & $\begin{array}{c}0.061 \\
(0.06)\end{array}$ & & $\begin{array}{c}0.121^{* *} \\
(0.04)\end{array}$ & \\
\hline Profitability & $\begin{array}{l}-0.185 \\
(0.23)\end{array}$ & & $\begin{array}{c}-0.256^{* *} \\
(0.08)\end{array}$ & \\
\hline Net Operating Loss Dummy & $\begin{array}{l}0.096^{*} \\
(0.04)\end{array}$ & & $\begin{array}{c}0.050^{* *} \\
(0.02)\end{array}$ & \\
\hline Investment Tax Credit Dummy & $\begin{array}{c}-0.047 \\
(0.04)\end{array}$ & & $\begin{array}{c}-0.067^{* * *} \\
(0.02)\end{array}$ & \\
\hline Constant & $\begin{array}{c}0.580^{* * *} \\
(0.08)\end{array}$ & $\begin{array}{l}0.382 \\
(0.21)\end{array}$ & $\begin{array}{c}0.566 * * * \\
(0.04)\end{array}$ & $\begin{array}{l}0.111 \\
(0.11)\end{array}$ \\
\hline Observations & 201 & 201 & 1,385 & 1,385 \\
\hline
\end{tabular}

Table 5 The table shows the two-stage least squares regression results with the coefficients for the explanatory variables over the three periods considered. Robust (clustered by firm) standard errors are reported in parentheses. Year dummies are included in the maturity regression to capture latent changes in the general economic environment. Significance is denoted as: ${ }^{* *} \mathrm{p}<0.001,{ }^{* *} \mathrm{p}<0.01, * \mathrm{p}<0.05$ 